\title{
VUp-Regulation of VCAN Promotes the Proliferation, Invasion and Migration and Serves as a Biomarker in Gastric Cancer [Corrigendum]
}

Cheng Y, Sun $\mathrm{H}, \mathrm{Wu} \mathrm{L}$, et al. Onco Targets Ther. 2020;13:8665-8675.

The authors have advised affiliation 1 on page 8665 is incorrect. The correct affiliation should read " ${ }^{1}$ Department of General Surgery, Nanjing First Hospital, Nanjing Medical University, Nanjing, Jiangsu, People's Republic of China".

The authors apologize for this error.

\section{Publish your work in this journal}

OncoTargets and Therapy is an international, peer-reviewed, open access journal focusing on the pathological basis of all cancers, potential targets for therapy and treatment protocols employed to improve the management of cancer patients. The journal also focuses on the impact of management programs and new therapeutic agents and protocols on patient perspectives such as quality of life, adherence and satisfaction. The manuscript management system is completely online and includes a very quick and fair peer-review system, which is all easy to use. Visit http://www.dovepress.com/ testimonials.php to read real quotes from published authors. 